\title{
The Internal Mechanism Research on Multi-stakeholder Cooperation Development of Engineering Higher Vocational Curriculum
}

\section{- Based on Collaborative Innovation Research Perspective}

Tianjin Vocational Institute Zhao Xueli, 300410

Tianjin Vocational Institute Zhang Haiyan, 300410

\begin{abstract}
This paper argues that it is necessary for multi-stakeholder cooperation to develop higher vocational curriculum, discusses the dynamic mechanism of cooperative development, and think the process essence is "multi-win" result of multi-agent collaborative innovation process, and is the fusion of many advantages. In the cooperation process, parties roles are different: government is guidance; higher vocational colleges are the main part of the curriculum construction, the concrete executor of higher vocational curriculum design guide, perpetrators; curriculum experts group play a dual role of guidance and evaluation based on theoretical vision for work-integrated learning course development; the role of industry enterprise varies according to the degree of their participation.
\end{abstract}

Keywords: Collaborative innovation; Engineering; Higher vocational courses; Cooperative development Author introduction:

Zhao Xueli, female (1978 -), Tianjin Ji county, Tianjin Vocational Institute Management College Lecturer, master degree, electronic commerce, EMAIL:zxltjttu@163.COM

Zhang Haiyan, female (1974, -), Hebei Chengan, Tianjin Vocational Institute Management College associate professor, Doctor of Management, construction. EMAIL:JUNSHI2002@163.COM

Fund project: This paper is the 12th Five-year Plan of Tianjin Education Science "Relying on 'Wisdom BinHai’, Carry out the Coordinated Development of Various Kinds of High Vocational Management Innovation Model Research and Practice (VE4065)" and "Outstanding Engineers Training Mode Research" (HE4020) two subjects research phases result.

In June 2010, Ministry of Education launched "Outstanding Engineers Education Training Plan". The program is of great importance to the demonstration and guide effect in higher education fostering talent demand for the society, adjusting the structure of talent training, improving the quality of talent training, promoting education teaching reform, and enhancing graduates employment ability. But the plan did not give more specific training mode and course plan. Therefore, this paper tries to explore multi-stakeholder cooperation development of higher vocational courses to enhance engineering personnel training quality.

\section{THE NECESSITY OF THE MULTI-STAKEHOLDER COOPERATION DEVELOPMENT OF HIGHER}

\section{VOCATIONAL CURRICULUM}

A. Response to the need of running subject diversification trend

In recent years, higher vocational education main body's diversification trend is increasingly apparent. The implementation of national vocational qualification system has relatively uniform standard. Under the guidance of uniform standard, it is possible for multi-stakeholder from the perspective of interests in their advantage to host and development related courses. And cooperative development course can avoid narrow course scheme, such as: social training institutions in the construction of talent cultivation focus too much on exam-oriented education. The constructor examination is the only goal, which weakens the course educating function. 
All kinds of social organizations make full use of its advantages for higher vocational education can open systematic higher vocational courses, and can open only one course. It is an indisputable fact that vocational school principals will be diversified. Course modular structure makes it possible to communicate and contact between different governance subjects. Education institutions open courses in their advantage, and students can choose to study different course module in different education institutions.

\section{B. Reduce the contradiction between talent supply and demand of college and enterprise}

Multi-stakeholder cooperation developing higher vocational course can to a certain extent, eliminate the contradiction between labor supply and demand.

Multi-stakeholder cooperation developing higher vocational course can largely enhance the pertinence and feasibility of curriculum content, and partly resolve structural unemployment problem.

Old course content, unprofessional talent was an important reason for conflicts of interest because of supply and demand structure imbalance of higher vocational education and employment market. From different professional employment in Tianjin Vocational College, a survey made by MYCOS Company, differences resulted from changes of industrial structure. Some emerging industries and the traditional industry disintegrated because it does not have the market prospect. These phenomena will be reflected on the employment of graduates, showing various professional graduates employment rate differences. At the same time, there is a change in the industrial structure on the market demand for graduates, mainly in the production department requiring skilled graduates, from basic level, more accumulate work experience, and that is to say, they will not be given more privileges. Vocational colleges' graduates' employment is similar to other labor configuration process in the Labor market, facing competition, selection experience. Graduates suitable for the knowledge structure of the Labor market are easy to get jobs; while those not suitable in the Labor market will get the result of elimination. For some students with old and not very professional knowledge and skills, basically they are not be valued by the market. Some higher vocational colleges' professional construction and reform are in slow pace, talent training scheme repeats undergraduate course, no characteristic and no advantage, the cultivation of high skilled talents can only stay on the slogan. It is difficult to keep up with the need of industrial development, and it is an objective reflection of the contradictions between high vocational education personnel training and employs units, which will cause imbalance of supply and demand of higher vocational education. Companies involving in curriculum development can be targeted to solve the problem of imbalance of supply and demand.

C. The conflict of interest of local economic demand and higher vocational education positioning Higher vocational education and regional economic development present interactive relationship. Area government agencies, industry associations and related enterprises participate in higher vocational curriculum construction on different levels, which will lead higher vocational education cultivate high-qualified talents for regional economic development, thereby promote regional human resources quality improvement, and optimize the structure of human capital; Depth of work-integrated learning in higher vocational colleges teachers and students provides information and technical support for regional economic development, and promotes transformation of science and technology, and realizes the scientific management of production and economy; use of curriculum resources in higher vocational colleges provides continuing education training for regional economic development, which has been in many colleges and universities. At the same time, regional economic development level determines the scale and speed of higher vocational education, restricts its purpose, structure, content and quality. Regional industry, technology decides higher vocational education professional structure, 
hierarchical structure; regional economic development level directly affects the employment of higher vocational graduates. Higher vocational education and regional economic relations are one of the fusions which show that the two are contradictory unity relations. Both sides only extend from each other in the developing and expand their development space. Ignoring the other and one-sided development of them will develop a deviation.

Influenced by traditional ideas, some higher vocational colleges' position is not clear, and takes education level status as ultimate pursuit, and is based on the school-running mode in undergraduate course of colleges and universities. As a result, heavy learning, light skills. Higher vocational education should begin from the development of work-integrated learning course to training to adapt to the high-skilled talents for social various frontline positions demand as the message, and highlight characteristics like applicability, operability, occupational, and regional.

\section{DYNAMIC MECHANISM OF MULTI-STAKEHOLDER COOPERATION DEVELOPING VOCATIONAL}

\section{COURSES}

\section{A. Seek "multi-win" result of multi-agent collaborative innovation process}

Collaborative innovation is an inter-organization, inter-departmental innovation behavior. In Automotive Engineering of Tianjin Vocational College, for example, many companies in different ways participate in automobile maintenance and marketing related courses construction and restructuring. On the one hand, enterprises actively participated in university curriculum construction work in order to cultivate employees, staff recruitment and staff training again and benefited; solve the problem of "labor shortage", and save employee training venues, facilities and teachers in terms of cost, also set a good image in cooperation colleges and universities students, and expand influence and brand awareness. The school factory cooperation, on the other hand, also brings higher vocational colleges and professional teaching recessive benefit. Especially there is targeted "orders" class teaching, which improves student's ability to adapt to jobs. There are more benefits for colleges and universities. In the school, they can finish the work of higher vocational teachers under enterprise training, face-to-face interaction of college teachers and enterprise training lecturer allows businesses scene the latest technological progress in a timely manner into university classroom, and at the same time improve enterprise training lecturer in related theory of literacy. The most obvious benefit is for college students. They can often hear lecture voice in the teaching building of senior technical personnel from enterprise, and enjoy enterprise style classroom teaching. What is the most valuable is that free training from company makes different teachers of higher vocational colleges to get to their own training base, and let these academic high tower "high culture" to enterprise workshop and carry out teaching aspects of academic discussion.

To sum up, according to the research achievements of game theory, cooperative development of higher vocational courses must be made to get the corresponding benefit to all parties to promote in-depth and smooth development of cooperative behavior. Cooperation process, therefore, must follow the basic law of cooperative game, stimulate deep cooperation will and interest of main body of higher vocational colleges, enterprises and industry training institutions, balance the interests of all parties, especially consider the needs of the enterprises, find the best combining site, complementary advantages, mutual support and coordinated development. At the same time, clear benefit distribution mechanism, avoid conflict; guarantee the stability of cooperation and sustainability. This is the basic premise of improving the efficiency of higher vocational curriculum development, and is the source of power of multi-agent collaborative innovation.

\section{$B$. The cooperation process is the fusion of many advantages}


The advantages of colleges and universities mainly focus on academic theory innovation, increase the depth of higher vocational curriculum development, and provide a solid theoretical basis for further study of higher vocational college students. This group controls the whole course design, and is with strong operability.

Enterprise's advantages are in its "high skills" "presence", and are a great way to avoid "driving a car on the blackboard". The specific implementation of higher vocational curriculum implements on each course unit design; the ideal cooperation way is for cooperative enterprises to control unit design of teachers. Considering the limitation of objective conditions such as time, higher vocational colleges usual practice is "please come in" enterprise direct teaching of skilled talents, school teacher in-class learning; Or "going out", sent the teachers of higher vocational colleges to enterprise internal "half field" internship for half a year, learn the skills within enterprise, and go to the classroom teaching.

The advantage of industry training institutions usually depends on training authority even monopoly in the industry, usually there is a natural teacher advantage. For example, construction in the field of engineering continues education training institutions, faculty are of various sources, which to a certain extent can implement many high quality teachers fusion of university teachers, teachers construction management and engineering field of high technology talented person and so on. Higher vocational engineering curriculum standards coordinated by the agency are relatively easy to implement.

To sum up, the development and principle of stakeholder cooperation developing higher vocational courses can realize the fusion of many advantages, and improve the integration quality of higher vocational education curriculum in our country. It is also higher vocational colleges' inevitable choice of survival and various competitive pressures.

\section{IN THE PROCESS OF MULTI-AGENT COOPERATION DEVELOPING HIGHER VOCATIONAL} CURRICULUM, EVERY PARTY’S ROLE IS DIFFERENT.

\section{A. Role positioning of government: guide rather than slogan}

1) Engineering professional consciousness from childhood

Teaching steering committee and industry steering committee and other organizations may face to the general public and carry out "month" activities to cultivate public consciousness of engineering profession, attract more people to work in engineering construction field, and enhance the supply level of engineering talents. "Month" activity can even carry out engineers "professional experience" activities in engineering talents training institutions for primary and middle school students, which will visualize engineer as a specific career.

This measure can not only guarantee the supply of engineering talent, but can reduce the burden of institutions of higher learning in the aspect of professional quality education, and make colleges and universities use more time to teach students new knowledge and new skills.

2) Relevant government departments can guide or even tempt related enterprises, social training institutions and vocational colleges, etc. to carry out course construction for depth of cooperation.

Government mainly promotes the deepening of technology combined education curriculum reform from the perspective of policy maker, and also can strengthen direction guidance in the form of policy suggestions.

B. Higher vocational colleges are the main part of curriculum construction, specific executives and practitioners of higher vocational curriculum design guide

Participating teachers on curriculum in higher vocational colleges play decisive role in the quality of overall design and unit design result. Facing "declining by quality" and "student number reducing" dual pressures, higher vocational colleges course builders have to try their best to improve the attraction of 
classroom teaching; this group in the process of curriculum development, therefore, plays an "active" role. Higher vocational colleges top and middle managers, and even the grass-roots level faculty, staff launch all forces that can be launched to actively carry out the course construction of university-enterprise cooperation, inter-school cooperation; actively cooperate with all kinds of industry games, adjust relevant curriculum content even subjects.

C. Curriculum experts group plays a dual role of guidance and evaluation of work-integrated learning course development from theoretical vision

Through their guidance, lead, design and guide work-integrated learning course development in correct direction; through scientific evaluation, ensure design quality orientation work-integrated learning course development achievements. Unfortunately, this kind of curriculum experts are too little, and it is difficult to achieve" one to one" curriculum development in higher vocational colleges in view of different characteristics.

$D$. The roles of industry enterprises vary according to the degree of their participation Enterprises have in-depth cooperation with colleges and universities, may be direct work-integrated learning course builder and direct beneficiary (such as: Changan Ford Training Center of Tianjin Vocational College, enterprise staff training center). Due to multiple reasons, enterprises failed to have in-depth cooperation may become course construction bystanders or advisor.

\section{REFERENCE}

[1]Yu Xiao. Engineering practice ability research orienting industry demand [D]. Zhejiang University. 2012.03 